\title{
[原著論文〕
}

\section{クワッドツリーを利用した 移動ロボットの高速経路生成アルゴリズム}

\author{
登尾啓史* 浪花智英**有本卓***
}

移動ロボットの実際的な障害物回避経路を高速に生成するアルゴリズムを提案する。このアルゴリズムは，作 業空間を上から撮影した実画像から怰率的に作成されるクワッドッリーといらモデル上で機能するので，作業空 間の障害物の配置の変化に柔軟に対応でさる。またクワッドッリーは作業空間のすべての領域を位置に関して 階層的に管理しているので, 移動ロボットより小さな領域を探索しないよらにすることにより口ボットと障害物 の干渉を調べなくても障害物回避経路が生成できる.

膨大な個数のノードを保持するクワッドッリーを直接的に探索して障害物回避経路を選択すると計算時間がか かる，とこで本研究では，クワッドッリー上にノード数を小さく括さえたパスグラフを展開し，それを探索する ことで間接的に障害物回避経路を選択し，アルゴリズムを高速化する。最後に，この高速性を従来の経路生成ア ルゴリズムとの比較で害験的に確認する.

\section{1. は じ め) に}

オペレータの指示なしに自律的に行動する移動ロボッ トには，障害物と衝突しない経路を自動的に生成する機 能が必要である、このため, ロボットの初期・最終位置 を与えるだけで障害物と衝突しない経路を生成するアル ゴリズム，すなわち“経路生成アルゴリズム”がこれま でいろいろと提案されてきだ〜4)。

しかし，これらが機能するモデルは膨大な計算時間の 前処理がなくては作成されないので, 障害物の配置が頻 繁に変化する作業空間では利用できない。すなわち，文 献1)の一般化錐体を作成するためほは， $O\left(n^{3}\right)$ の計算 量の処理が必要となる（ $n$ : 障害物を表現する多角形の 頂点数). 委た，文献 ${ }^{2) ~ 4)}$ の可視グラフやクワッドッリ 一を作成するためには，作業空間の障害物領域を侵入禁 止領域（点で表現された口ボットが侵入不可能な領域） に成長させることでロボットを点に㷌着させる、いわゆ る“Growing Obstacle”といら処理を行なったらえで その侵入禁止領域を可視グラフやクワッドッリーに変換 しなければならないが，これには膨大な計算時間が必要 になる，さらに，侵大禁止領域の可視グラフを作成する

原稿受付 1988 年 8 月 24 日

* 大阪電気通信大学工学部 $* *$ 大阪大学基整工学部

**** 東京大学工学部
ときや任意に選択される初期・最終位置のノードを可視 グラフに追加するときにはノード間の可視性を調べなけ ればならないが，侵入禁止領域の形状が複雑なときには これにも膨大な計算時間がかかる2).

また，それらのアルゴリズムは必ずしも高速に実際的 な障害物回避経路を生成しない。一般に, 経路生成アル ゴリズムは動的計画法や $\mathrm{A}$ *法などでそのモデルを探索 するが，動的計画法はモデルのノード数 $n$ に依存した 個数のノードを探索し，A* 法も探索を最終位置に導 くヒューリスティック情報を持たないときには多数のノ ードを探索する。任意の初期・最終位置を結ぶ少しでも 短い障害物回避経路を獲得しようとすればするほど侵入 禁止領域を表現するモデルのノード数が増加するので, それらのアルゴリズムは膨大な計算時間が必要となる。

そこで本論文では，障害物の配置が頻繁に変化する作 業空間でも高速に機能する実用的な経路生成アルゴリズ ムを提案する。このアルゴリズムは，作業空間を上から 撮影した実画像から直接作成されるクワッドッリー上で 機能し，その画像は“Growing Obstacle“という処理 を経ずに障害物領域をそのまま表現するので，障害物の 配置が頻繁に変化する作業空間に执いて子利用できる.

このクワッドッリーではロボットは点に帰着されてい ない.しかし，ロボットの形状がクワッドッリーのノー ドが表現する領域で近似できる程度に簡単なものであれ 
ば,クワッドッリーの階層構造を利用してその領域より 小さい自由領域と障害物領域を侵入禁止領域にすること で、ロボットと障害物の干渉を調べなくてもロボットと 同じかそれより大きい自由領域の列がロボットの障害物 回避経路として獲得できる。ここで，この列は複数の障 害物回避経路を含み，そのいくつか（例えば，自由領域 が接する部分の中点を線分と円弧で結ぶ経路）は容易に 取り出せるので，ロボットの障害物回避経路とみなすこ とができる。この方法は口ボットのスケールに応じて侵 入禁止領域を容易に変化させることができるので，口ボ ットの変更に柔軟に対応でさる.さらに, 複数の口ボッ トが作業空間を移動するとき，文献４の方法では個々の ロボットにクワッドッリーを割り当てなければならない ので，それを作成する計算時間や記憶する容量がロボッ トの個数に比例して大きくなるのに対し，提案する方法 では作業空間にクワッドッリーを割り当てればよいので それらはロボットの個数に依存しない，したがって，こ の方法は複数のロボットの障害物回避経路の生成に和い ても有效に利用できる

さて，この経路生成アルゴリズムの高速化を考える。 一般に，クワッドッリーは膨大な個数のノードを保持す るので，それを直接的に探索して障害物回避経路を高速 に獲得することは困難である。そこで本研究では，“胨 スグラフ”と呼ばれるグラフをクワッドッリー上に展開 し，それをできるだけ小さく保らながら間接的にクワッ ドッリーを探索することでアルゴリズムを高速化する.



Obstacle

\section{Black region}

White region
パスグラフはもとのクワッドッリーはもやろん可視グラ フと比較しても非常に小さく保たれるので，提案する経 路生成アルゴリズムはこれまでのものに比べて高速に機 能する。

\section{2. モデルの定義}

この経路生成アルゴリズムでは, 経路の選択はパスグ ラフ上で行われ，パスグラフのアークに対応する線分と 侵入禁止領域の交差判定や線分が交差する侵入禁止領域 の回避位置の選択はクワッドッリ一上で行われる。この 章では,これらのモデルについて説明する。

\section{1 クワッドツリー}

クワッドッリーは，2次元空間のすべての領域を位置 に関して階層的に管理するモデルである6,7)。このクワ ッドッリーでロボットの作業空間を表現すると, 障害物 領域と自由領域が統一的に管理できる (Fig. 1).

クワッドッリーでは, 障害物が占有する領域（障害物 領域）は黒ノード, 障害物が存在しない領域（自由領 域）は白ノード，障害物は存在するが占有しない領域は ミックスノードで表現される。ミックスノードに対応す る領域は 4 つのサブ領域に分割され，それらはミックス ノードの子ノードによって表現される。子ノードの番号 と表現する領域の位置の対応はFig. 1 のよに定義され る・階層的に種々の大きさの領域を管理するクワッドッ リーのレベルはルートから昇順に番号づけられており, このレベルはノードに対応する領域の大きさを表わす (Fig. 1).

ロボットの作業空間を表現するクワッドッリーは，そ れを上から撮影した実画像から高速に作成できる。すず， 濃淡情報や色情報等を単純に利用して，カメラから得ら れた実画像を障害物領域と自由領域が区別された 2 值画 像に変換する ${ }^{8}$ 。次に, この 2 值画像において同じ領域 情報をもつ4つの隣接する領域を再帰的に統合すると, 障害物領域と自由領域を管理したクワッドッリーが作成 される9 (Fig. 2 (a)).

さて,このクワッドッリーをそのまま利用して障害物

(a)

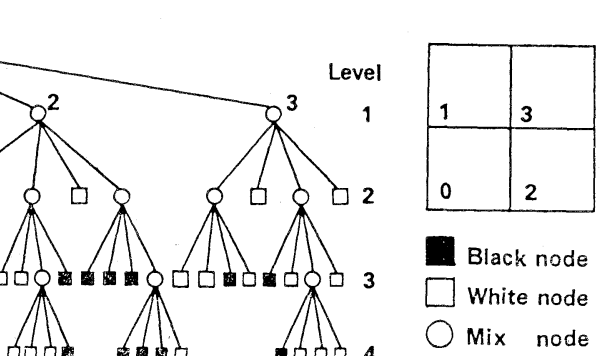

(b)

Fig. 1 A workspace ( $a$ ) and its corresponding quadtree (b) 


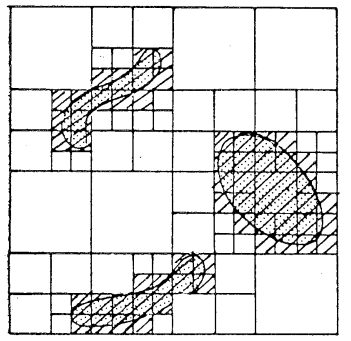

Work space

(a)

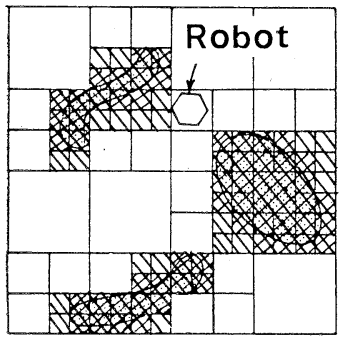

Work space

(b)

Fig. 2 Free and obstacle regions in a workspace (a), free and forbidden regions for a mobile robot in the workspace (b)

回避経路を探索しようとすると、ロボットと障害物領域 の干渉を逐次調べなければならなくなり計算時間がかか る。そこでわれわれは，口ボットより大きいかそれと等 しい最小の領域に対応するノードのレベル一以後探索レ ベルクと呼ぶーのミックスノードを黒ノードとみなすこ とで, ロボットより小さい自由領域を障害物領域ととも 飞侵入禁止領域（黒ノード）とする(Fig.2(b))。こ のようにすると， ロボットと障害物領域の干渉を調べな くても, ロボットの障害物回避経路がロボットと同じか それより大きい自由領域の列として獲得できる。

クワッドッリーを前処理しないこの方法は, ロボット の変更に柔軟に対応できるら光，作業空間を移動する複 数のロボットの経路計画にも有効に利用できる.

\section{2 パスグラフ}

膨大な個数のノードを保持するクワッドッリーを直接 的に探索することで実際的な障害物回避経路を高速に選 択するのは困難である。そこで本研究では，クワッドッ リー上に“パスグラフ”と呼ばれるグラフを展開し，そ れを探索することで実際的な障害物回避経路を間接的に 選択している (Fig. 3). このパスグラフを小さく保つ ことによってアルゴリズムは高速化される10),11).

パスグラフのノードは作業空間に和ける位置を表現し，

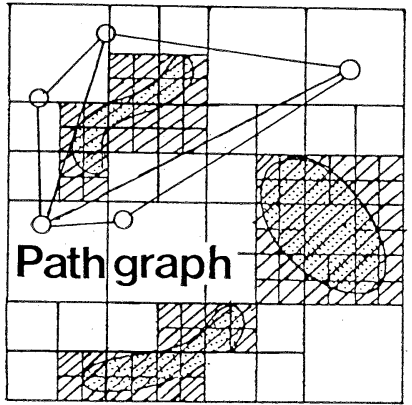

Quadtree

Fig. 3 A path graph on the quadtree

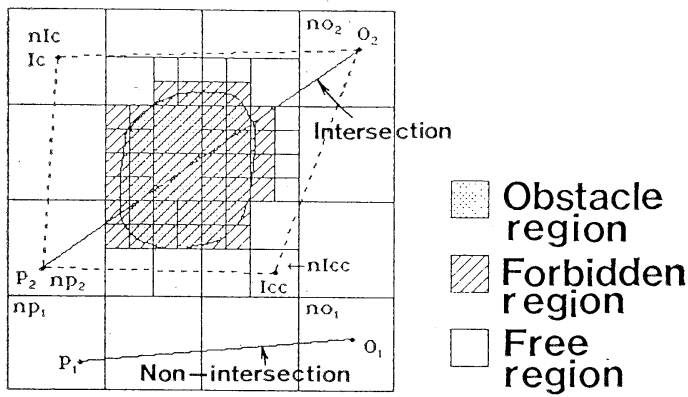

Fig. 4 Assignment of a binary sign (0: Nonintersection, $1:$ Intersection) and a cost for each arc

アークは両端のノードの位置を結ぶ線分を表現する。例 えば，パスグラフのスタート・ゴールノードはそれぞれ 作業空間の初期・最終位置を表現し，それらを結ぶア一 クは初期・最終位置を結ぶ線分を表現する。

パスグラフは侵入禁止領域を全く考慮せず小さく保た れるよらに生成されるので，そこには侵入禁止領域と交 差する線分に対応するアークが存在する.このことから， アークは侵入禁止領域との交差・非交差を表現する 2 值 情報を保持する。ささらに, アークはパスグラフから最短 経路を選択するときに利用するコストも保持する。ここ で, パスグラフの経路はスタート・ゴールノードを結ぶ アークの列で表現され，そのコストはそれらのアークの コストの総和で定義ざれる。そして，そのコストの最小 のものがパスグラフの最短経路となる.

これらのことから, 侵入禁止領域と交差しない線分 $L$ $=P_{1} O_{1}$ に対応するアークは，1）非交差を表現する 2 値 情報 “0”，2）線分 $L$ のユークリッド距離 $E\left(P_{1} O_{1}\right)$ を コストとして保持する. 侵入禁止領域と交差する線分 $L=P_{2} O_{2}$ に対応するアークは，1）交差を表現する 2 值 情報 “ 1 ”，2）侵入禁止領域の回避位置 $I_{c}, I_{c c}$ (対応する クワッドッリーの回避ノード $\left.n_{I_{c}}, n_{I_{c c}}\right), 3$ ) 回避位置を経 
由乙て線分 $L$ 端点を結ぶ $2 つ$ 線分のユークリッド距 離の和の最小值 $\min \left\{E\left(P_{2} I_{c}\right)+E\left(I_{c} O_{2}\right), \quad E\left(P_{2} I_{c c}\right)+\right.$ $\left.E\left(I_{c c} O_{2}\right)\right\}$ をコストとして保持する (Fig. 4).

\section{3. 経路決定アルゴリズム}

提案するアルゴリズムは，パスグラフの最短経路が侵 入禁止領域を回避するまで, その最短経路の選択とパス グラフの拡張を同期的に行なう。このアルゴリズムでは, まず初期・最終位置に対応するスタート・ゴールノード を結ぶアークで最初のパスグラフを定義し，次にパスグ ラフから最短経路を選択する。最後に，パスグラフの最 短経路が侵入禁止領域と交差しなければ，最短経路が通 過する自由領域の列をロボットの障害物回避経路として 選択しアルゴリズムは終了する，そうでなければ，侵大 禁止領域と交差するアークを削除したらえで，その回避 ノードやそれと削除したアークの両端のノードを結ぶア ークを新たに登録することでパスグラフを拡張し最短経 路の選択に戻る。

ここで，最短経路と侵入禁止領域の交差を判定するも とになるアークが表現する線分と侵入禁止領域の交差判 定ならびに交差する侵入禁止領域の回避位置の選択は クワッドッリー上で行われる。

3.1 節では, アークが表現する線分 $L$ と侵入禁止領域 の交差を調べる方法, 3.2 節では, 線分 $L$ が交差する侵 入禁止領域の回避位置を選択する方法を説明する. 3.3 節では，アルゴリズムの中心処理であるパスグラフから



\section{Obstacle}

Forbidden region

Free region

Search region

Search level

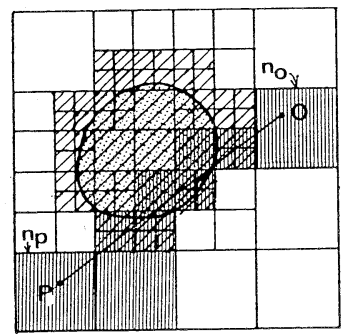

Obstacle

Forbidden region

Free region

Search region

Search level

Fig. 5 Interference check between the edge $L$ and the forbidden region in the quadtree
の最短経路の選択とパスグラフの拡張を同期的に行なら 方法について説明する.

\section{1 線分 $\boldsymbol{L}$ 亡侵入禁止領域の交差判定}

パスグラフにアークを新たに登録するとき，対応する 線分が侵入禁止領域と交差するか否かを表わす 2 值情報 “0”，“1”を割り当てる. ここでは，線分 $L$ と侵入禁止領 域の交差をクワッドッリー上で効率的にチェックする方 法, すなわち, 探索レベル $n$ 以下のレベルのノード（領 域）のらち線分 $L$ 亡交差するものを辿り，侵入禁止領域 （黒ノード）を通過するとき線分 $L$ と侵入禁止領域は交 差と判定する方法について具体的に説明する.

[ステップ 1] 線分 $L$ の両端の位置 $P, O$ に対応する クワッドッリー上のノードをそれぞれ $n_{P}, n_{O}$ とし， ード $n \leftarrow n_{P}$ とする.

[ステップ 2］位置 $P$ から位置 $O$ ヘのベクトルにそっ てノードnの隣接ノード $n^{\prime}$ を選択する。この処理には 文献 ${ }^{12)}$ のアルゴリズムが利用される.

[ステップ 3$]$ ノードnを集合 $S$ に登録したあとノ一 ド $n \leftarrow n^{\prime}$ とする. ここで，ノードnは集合 $S$ に順々に 登録される。

[ステップ 4] ノード $n=n_{0}$ となれば，ノード $n$ を 集合 $S$ に登録して [ステップ5]を行ら。そうでなけれ ば [ステップ2] に戻る。

[ステップ 5] 集合 $S$ に黒ノード（侵入禁止領域）が 存在するとき, 線分 $L$ は侵入禁止領域と交差する (Fig. 5).

したがって, 集合 $S$ に黒ノード（侵入禁止領域）が存

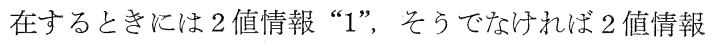
“0”をアークに割り当てる.

線分 $L$ が侵入禁止領域と交差するときにはとの回避位 置を選択しなければならない。一般に，移動口ボットは 時計回りか反時計回りに侵入禁止領域を回避するが，ぞ ららを選択すればュストの小さい経路が得られるかは口 一カルにではなくグローバルに考觉なければわからない、 またどちらか一方にしか侵入禁止領域を回避できない こともある.したがって，このアルゴリズムではどらら の可能性も残すため, 起点ノード（線分 $L$ が侵入禁止領


入禁止領域から出るときの白ノード）まで時計回りと反 時計回りに侵入禁止領域（黒ノード）周囲の自由領域 （白ノード）を辿り回避位置を各々選択する.

\section{2 侵入禁止領域の回避位置の決定}

パスグラフにアークを新たに登録するとき，対応する 線分 $L$ が交差する侵入禁止領域を回避するための位置を 割り当てる. 侵入禁止領域の回避位置は, 探索レベル $n$ 以下のレベルの自由領域（白ノード）を侵入禁止領域に 
沿って起点ノードから終点ノードまで辿ることで選択す るが，例えばFig.6(b)の様にどちらかのノードが侵入 禁止領域に囲まれているとさにはそれらのノードは迻れ ない，そこで, 線分 $L$ が侵入禁止領域に入るときの白， 一ドを待ち行列 $Q$, 線分 $L$ が侵入禁止領域から出るとき の白ノードを待ら行列 $Q^{\prime}$ に登録し, もし辿れなければ 待ち行列から次のノードを取り出して再度辿ることで,

起点ノードから終点ノードまで侵入禁止領域を確実に辿 り，線分Lからのニークリッド距離が最大の自由領域の 中心点を回避位置として選択する方法を説明する（Fig. 6).

尚, 線分Lからのユークリッド距離が最大の自由領域 の中心点を回避位置として選択する理由は, その自由領 域を経由して線分Lの両端を結ぶパスが侵入禁止領域を 回避する最短パスの候補になるからである。この理由は, それ以外の自由領域を経由して線分 $L$ の両端を結ぶパス は再び侵大禁止領域と交差する可能性があるからと言い 換えることができる.


(a)
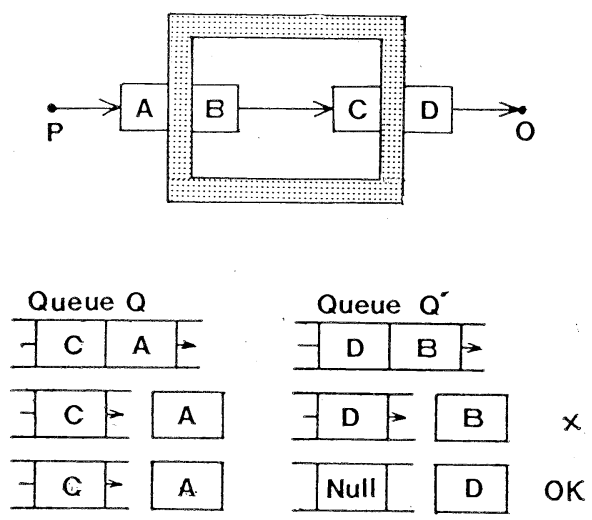

(b)

Fig. 6 Determination of a pair of two white nodes in which the edge $L$ enters into and gose out of the forbidden region
[ステップ1] 待ち行列 $Q ⿱ Q^{\prime}$ から先頭ノードのペ アを取り出す。待ち行列ではすべてのノードは先頭から 昇順に番号つけられているので， $a \leftarrow 0, b \leftarrow 0$ とし，待 ら行列 $Q, Q^{\prime}$ から白ノード $n_{a}, n_{b}$ を取り出す.

[ステップ2］文献 ${ }^{13)}$ のアルゴリズムを利用して，侵 入禁止領域 (黑ノード) の周囲の自由領域 (白ノード)を ノード $n_{a}$ からノード $n_{b}$ まで時計回りと反時計回りに 辿る. そしてノード $n_{b}$ に到達したときのみ, 線分しか らのコークリッド距離が最大の自由領域（クワッドッリ 一のノード $\left.n_{I c}, n_{I c c}\right)$ の中心点を回避位置として選択 する (Fig. 7).

[ステップ 3] 待ち行列 $Q$ または $Q^{\prime}$ が空になれば, すべての回避位置を保持して終了する。そうでなければ， ノード- $n_{b}$ に到達したときには， $b \leftarrow b+1, a \leftarrow b, ノ 一$ ド $n_{b}$ に到達しなかったときには， $a \leftarrow a, b \leftarrow b+1$ とし て待ち行列 $Q, Q^{\prime}$ から白ノード $n_{a}, n_{b}$ を取り出し [ᄌ テップ2]に戻る.

線分 $L$ が複数の侵入禁止領域と交差するとき，この手 続きは侵入禁止領域毎に回避位置を選択する (Fig. 8).

\section{3 パスグラフからの最短経路の選択}

膨大な個数のノードを持つクワッドッリーを直接的に 探索することでは，実際的な障害物回避経路を高速には



Obstacle region Forbidden region Free region Search region

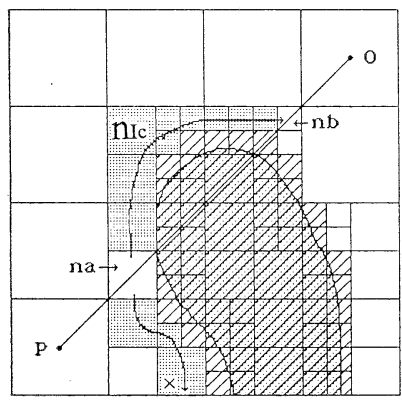

Obstacle region

\begin{tabular}{|c|c|c|c|c|}
\hline & \\
\hline & $\begin{array}{l}\text { orbidder } \\
\text { egion } \\
\text { ree }\end{array}$ \\
\hline
\end{tabular}

Fig. 7 Selection of intermediate nodes by tracing white nodes around the forbidden region 
選択できない，そこで本研究では，パスグラフをクワッ ドッリー上に動的に作成し，それを出来るだけ小さく保 らながら間接的にクワッドッリーを探索することで，実 際的な障害物回避経路を高速に選択している.

ここでは，提案するアルゴリズムの中心処理であるパ スグラフからの最短経路の選択とパスグラフの拡張につ いて説明する。

[ステップ 1] 初期位置と最終位置を表わすスタート ノードSとゴールノードGを結ぶアークで最初のパスグ ラフを定義する。このとき，既に説明したクワッドッリ 一上での $2 つ の$ 処理を行ない, 侵入禁止領域との交差, 非交差を表わす 2 值情報 “ 0 ”, “ 1 ”，そ乙て侵入禁止領域 を回避するための位置をアークに割り当てる。

[ステップ2］ Dantzig'14) のアルゴリズムを利用して スタートノードSからゴールノード $G$ をでの最短経路を 現在のパスグラフから選択する. Dantzig のアルゴリズ ムの計算量は $O(n d)$ と評価される（ $n$ : パスグラフの
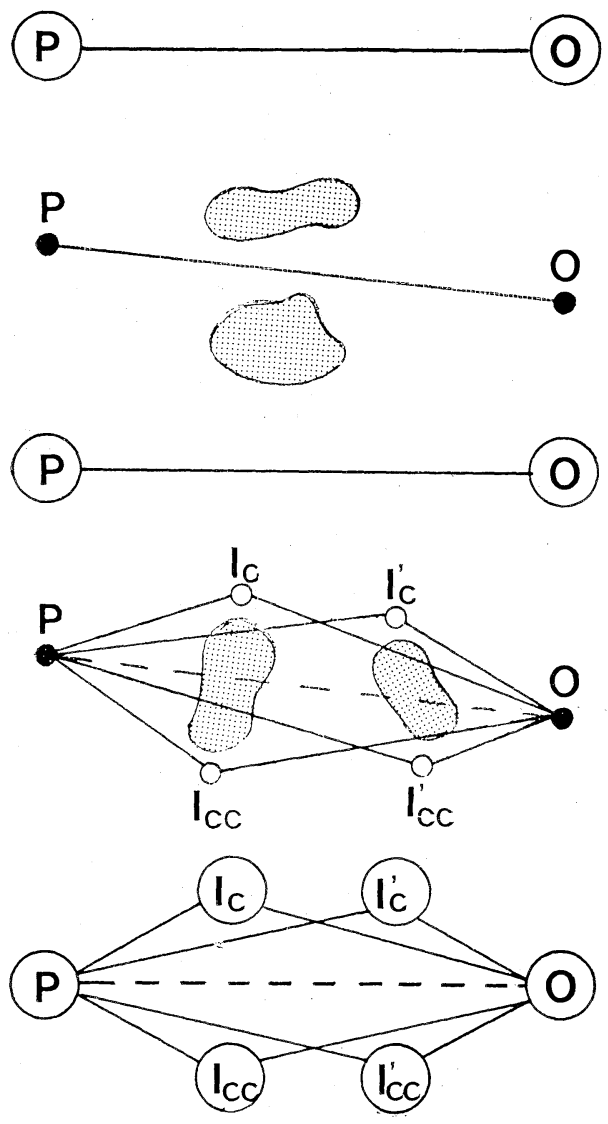

Fig. 8 Selection of intermediate nodes when the edge $L$ collides with several forbidden regions
ノード数, $d$ : パスグラフのノード平均分岐数).

[ステップ 3］選択された最短経路のすべてのアーク が 2 值情報 “ “0”を持つとき, 最短経路が通過する自由 領域の列をロボットの障害物回避経路としてアルゴリズ ムは終了する（Fig.9（a))。そうでなければ，【ステ ップ 4] に進む.

[ステップ 4] 最短経路を構成するアークのなかで 2 值情報 “1”を持らコストが最大のものを選択し，それ が保持する回避位置を表現するノードをパスグラフに追 加する (Fig. 9 (b)).

[ステップ 5] 選択されたアークをパスグラフから削 除すると同時にそのアークの両端ノードと回避ノードを 結ぶアークをパスグラフに追加する．このとき，既に説 明したクワッドッリー上での $2 つ の$ 処理を行ない，侵入 禁止領域との交差，非交差表表わす 2 值情報 “0”，“1”， そして侵入禁止領域を回避するための位置をアークに割 り当てる。これらのアーク浪最短経路を選択するの必 要であり,これらの処理によりパスグラフは更新される (Fig. 9(c))。そして [ステップ2］に戻る。

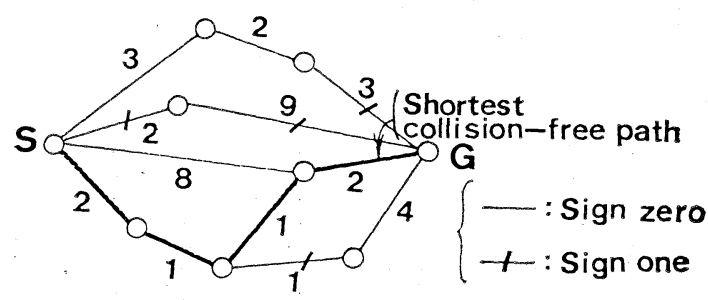

(a)

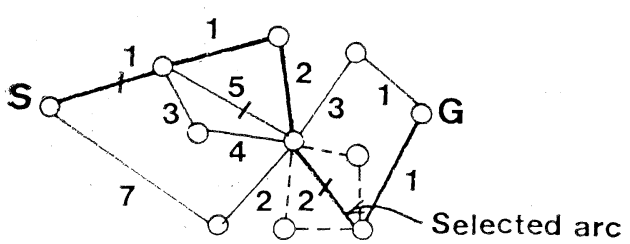

(b)

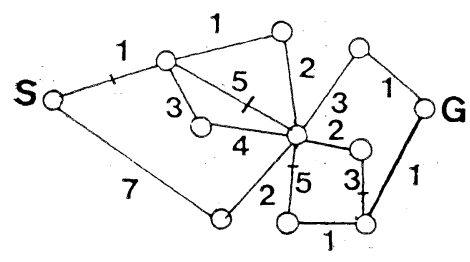

(c)

Fig. 9 Expansion of the path graph 


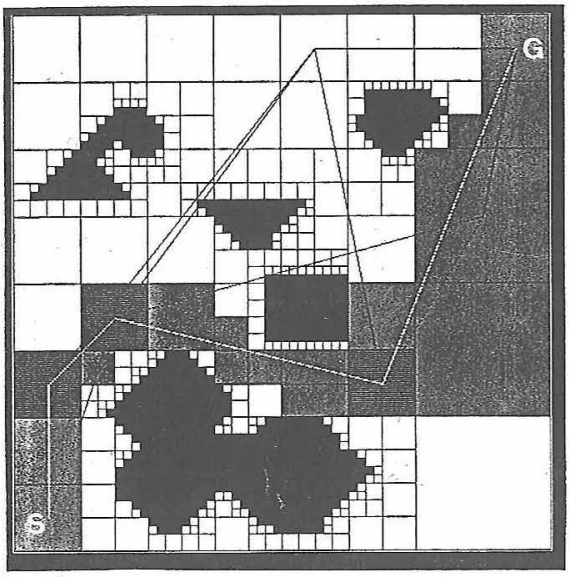

(a) Workspace 1



(b) Workspace 2

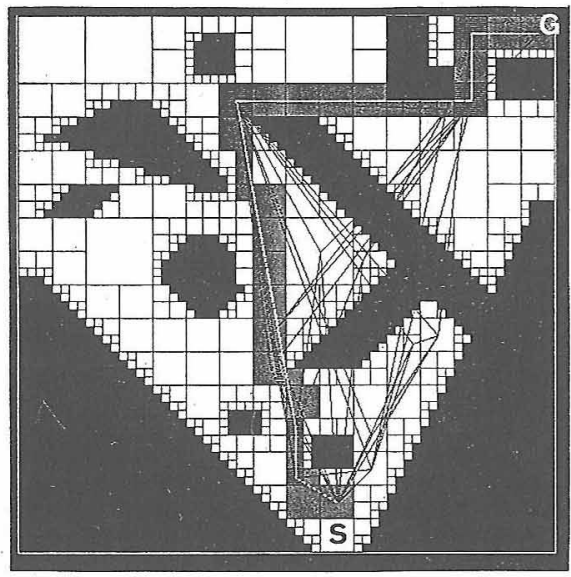

(c) Workspace 3
Table 1 Comparison of calculation times of our algorithm and Kambhampatis one

\begin{tabular}{ccccc}
\hline \multirow{2}{*}{ Horkspace Level } & \multicolumn{3}{c}{ Calculation time (second) } \\
\cline { 3 - 5 } & & Proposed algoritho & $\begin{array}{c}\text { Kambhampati's algoritho } \\
\text { Pure } \AA^{\circ}\end{array}$ Modified $\AA^{\circ}$ \\
\hline 1 & 4 & 0.233 & 28 & 11 \\
2 & 4 & 0.566 & 54 & 12 \\
3 & 5 & 2.250 & 84 & 16 \\
4 & 4 & 1.433 & 38 & 12 \\
5 & 4 & 2.883 & 58 & 13 \\
\hline
\end{tabular}

Table 2 Comparison of algorithms running on the path graph and the VGRAPH with respect to the calculation time

\begin{tabular}{ccccc}
\hline \multirow{2}{*}{ Experiment } & \multicolumn{2}{c}{ Position } & \multicolumn{2}{c}{ Calculation time (second) } \\
\cline { 2 - 5 } & Start & Goal & $\begin{array}{c}\text { Path graph } \\
\text { (level 4) }\end{array}$ & $\begin{array}{l}\text { VGRAPH } \\
\text { (54 nodes) }\end{array}$ \\
\hline \multirow{2}{*}{1} & $(270,32)$ & $(450,200)$ & 0.025 & 0.183 \\
2 & $(32,250)$ & $(450,200)$ & 0.033 & 0.188 \\
\hline
\end{tabular}

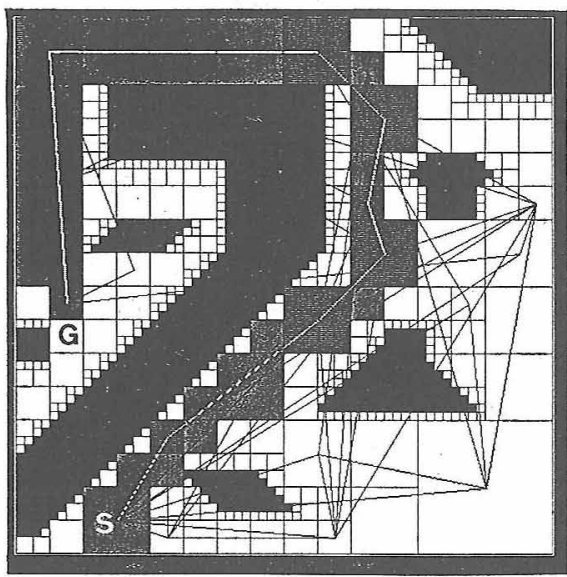

(d) Workspace 4

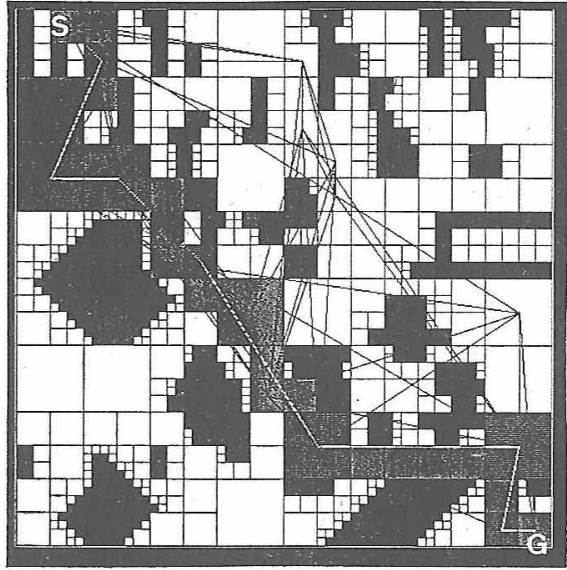

(e) Workspace 5

Fig. 10 Several workspaces used in the Kambhampati's paper ${ }^{4)}$ 


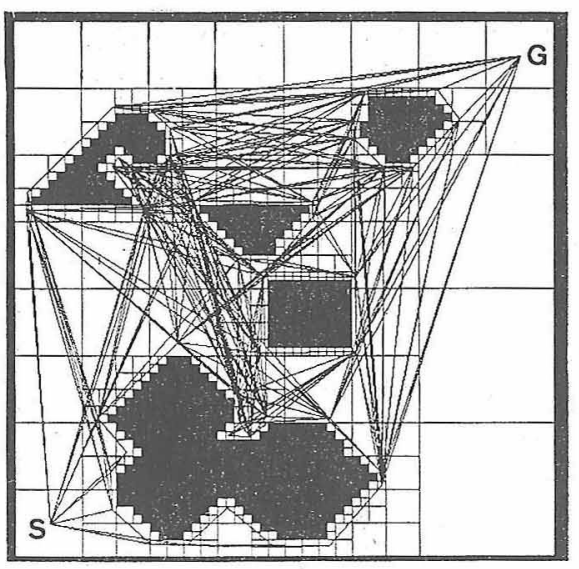

(a)

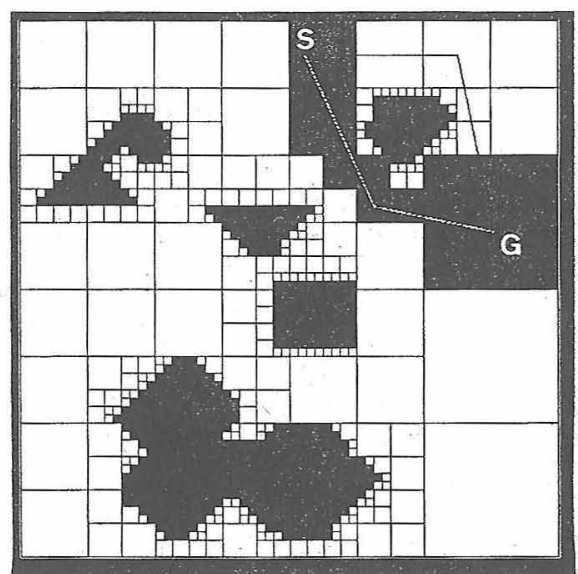

(b)

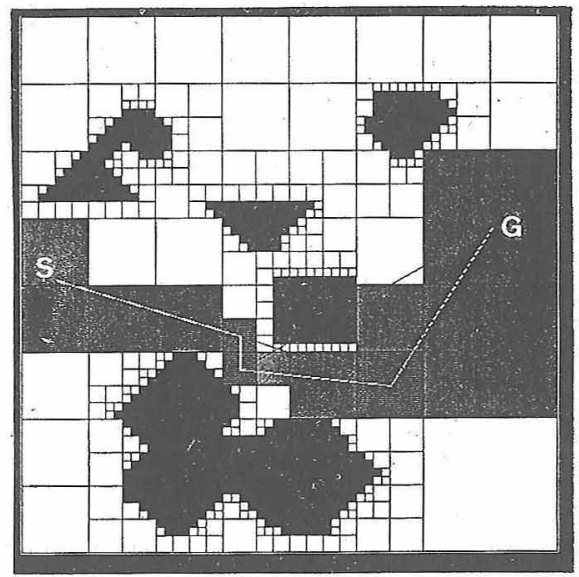

(c)

Fig. 11 A VGRAPH with fifty-four nodes on the quadtree ( $a)$, an experiment $1(b)$ and an experiment 2 (c) on the path graph and the VGRAPH

\section{4. 実 験 結 果}

この章では，まず，提案した経路生成アルゴりズムの 計算時間とこれまでの経路生成アルゴリズムの計算時間 を比較し，我々のアルゴリズムの高速性を確認する．次 に，障害物回避経路の距離やクワッドッリーの探索レベ ルnの変化に関して我々のアルゴリズムの計算時間のふ るをいを調べる。

\section{1 Kambhampati のアルゴリズムとの計算時間の} 比較

文献4)と同じ形状の作業空間を利用して，我々のアル ゴリズムの計算時間と Kambhampati のアルゴリズム の計算時間を比較する (Fig. 10).これらのアルゴリズ ムが必要とする計算時間を Table 1 に示す. 我々のア ルゴリズムは Apollo DN $590 \mathrm{~T}$ の AEGIS 上のC言 語, Kambhampati のアルゴリズムは Vax 11/785 上の Franz-Lisp で記述されているので，厳密にはそれらの 計算時間は比較できないが, Table 1 の結果やそれらの 計算機のベンチマークテストの結果から, 我々のアルゴ リズムは Kambhampati のアルゴリズムよりも高速で あると考觉られる。

4.2 可視グラフを $\mathbb{A}^{*}$ 法で探索するアルゴリズムと の計算時間の比較

我々のアルゴリズムの計算時間と可視グラフを $\mathrm{A}$ * 法 で探索するアルゴリズムの計算時間を比較する。ここで む, 同じ形状の作䉾空間を利用して実験を行ない, 可視 グラフはクワッドッリーの黑ノードの集合を近似した多 角形にるとついて作成されている，また，可視グラフを A*法で探索するアルゴリズムでは，スタート・ゴール ノードと侵入禁止領域の可視グラフのノードとの可視性 は 3.1 節の方法を用いてクワッドッリ一上で効辩的に判 断している (Fig。11).

2つのアルゴリズムの計算時間を示す Table 2. の結 果から, 我々のアルゴリズムは可視グラフを $\mathrm{A}$ *法で探 索するアルゴリズムよりも高速であることがわかる.こ の理由としては，侵入禁止領域の可視グラフが多数の) ードを持つので, スタート・ゴールノードと侵入禁止領 域の可視グラフのノードとの可視性を調べるのに計算時 間がかかることがあげられる。

可視グラフを A*法で探索するアルゴリズムでは，よ り短い障害物回避経路を獲得するため侵入禁止領域を表 現する可視グラフのノード数を増加させなければならな いが，それにつれてアルブリズムの計算時間が膨大にな る.このことは自然形状の障害物が存在する作業空間に おいて顕著に現れる、したがって，このアルゴリズムは そのような障害物が多数存在する作業空間には適用しに 


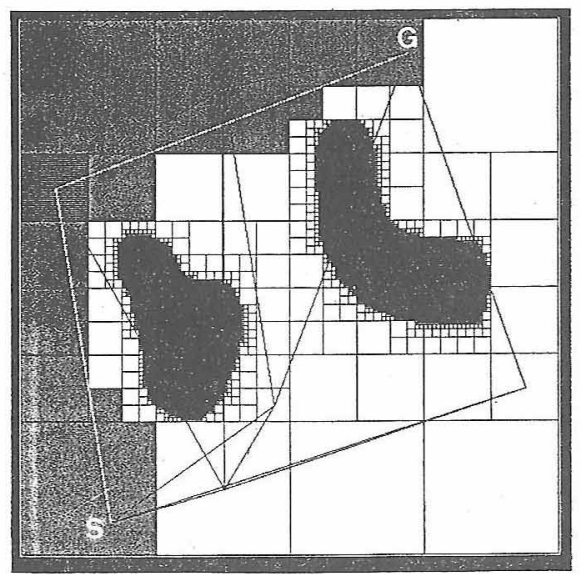

Fig. 12 Free shaped obstacles and its path graph

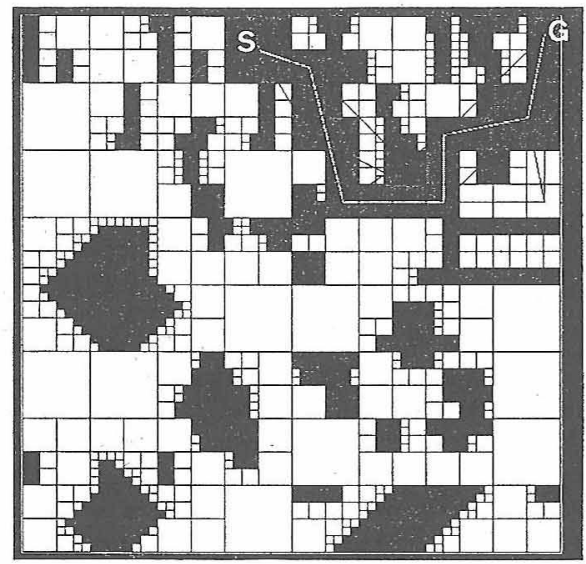

(a)



(b)

Fig. 13 Selection of different collision-free path (a) and (b) in the workspace 5 <w.

これに対して，パスグラフは侵入禁止領域每に高々数 個の回避ノードしかとらないので，提案したアルゴリズ ムの計算時間は自然形状の障害物が存在する作業空間に おいても殆ど増加しない（Fig。12）．我々のアルゴリズ ムはグローバルには最短経路に近い実際的な障害物回避 経路を選択するので, 可視グラフを A * 法で探索するア ルゴリズムよりも実用的な面で優れていると考光られ ๖.

\section{3 提案したアルゴリズムの性質}

このアルゴリズムでは，初期・最終位置を結ぶ実際的 な障害物回避経路を選択するための必要最小限の大きさ のパスグラフしか作成しないので，2つの位置が接近し

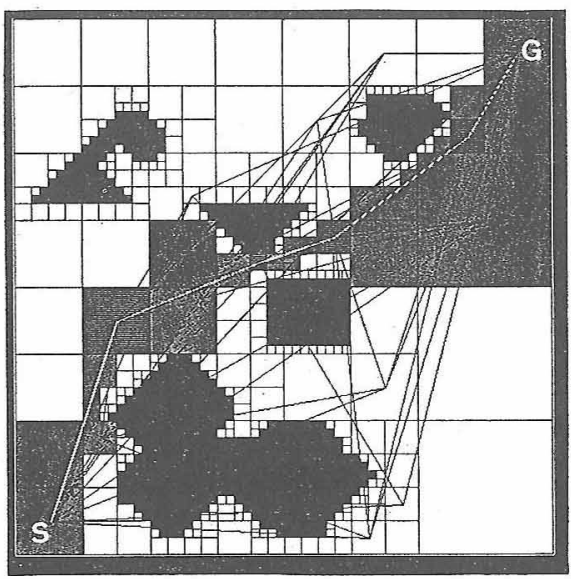

(a)

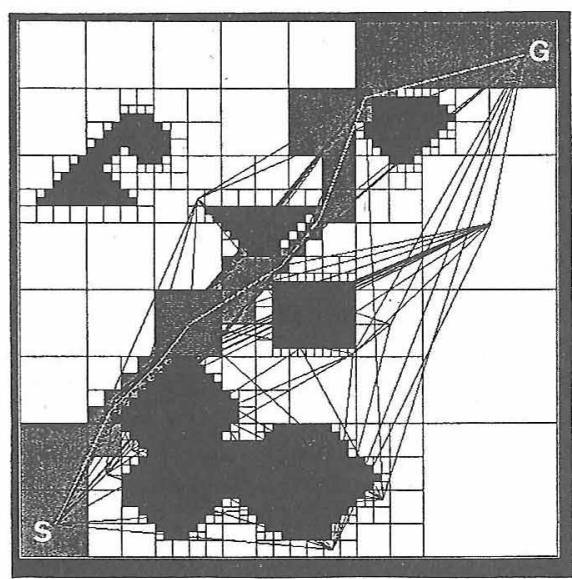

(b)

Fig. 14. The shortest collision-free path when the search level is changed in the workspace 1 , the level five (a), and $\operatorname{six}(b)$ 
ているときアルゴリズムは高速に機能する.4.1 節で利 用した作業空間 5 (Fig. 10 (e)) で初期・最終位置をFig. 13 のように変えたとき, 障害物回避経路を求めるのに 必要な計算時間は各々 $0.250,0.783$ 秒となる（後者は 探索レベル 5 でクワッドッリーを探索している)。

また，ロボットのスケールに応じてアルゴリズムの探 索レベルnを変化させたときの障害物回避経路とアルゴ リズムの計算時間の変化を調べる. 4.1 節で利用した作 業空間 1 (Fig. 10 (a)) で探索レベルnを 5 やとした ときの障害物回避経路を Fig. 14 に示す.このときのア ルゴリズムの計算時間は各々 $1.383 ， 6.183$ 秒となる.

探索レベル $n$ を大きくするとクワッドッリ一上で探索 しなければならないノード数が指数的に増加し, それに つれてアルゴリズムの計算時間も増加する。

\section{5.むす び}

これまでの経路生成アルゴリズムは膨大な計算時間の 好理を経て作成されるモデルの上でしか機能しないので 障害物の配置が頻繁に変化する作業空間には適用できな い.また，それらは膨大な個数のノードを保持するモデ ルを $A$ * 法や動的計画法で探索するので多大な計算時間 を必要とする。

そこで本論文では，これらの問題点を解決した害用可 能な移動ロボットの経路生成アルゴリズムを提案した。 作業空間を上から撮影した実画像から高速に作成される クワッドッリー上で機能するこのアルゴリズムは, 障害 物の配置が頻繁に変化する作業空間にもとのまま適用で きる。

またアルゴリズムは膨大な個数のノードを持つクワ ッドッリーを直接的に探索するのではなく，クワッドッ リーの上に小さく展開されたパスグラフを間接的に探索 して和り，これまでのアルゴリズムに比較して実際的な 障害物回避経路が高速に決定できる。

\section{参考 文 献}

1) R.A.Brooks, "Solving the Findpath Problem by Good Representation of Free Space, "IEEE Trans. on Systems, Man and Cybernetics, Vol.SMC-13,
No.3, pp. 190-197, 1983

2) T. Lozano-Pérez and M. A. Wesley, "An Algorithm for Planning Collision-Free Paths among Polyhedral Obstacles," Commun. ACM, Vol..22, pp.560-570, 1979

3) T. Lozano-Pérez, "A Simple Motion-Planning Algorithm for General Robot Manipulators," IEEE Journal of Robotics and Automation, Vol. RA-3, No.3, pp. 224-238, Jan. 1987

4) S. Kambhampati and L.S. Davis, "Multiresolution Path Planning for Mobile Robots." IEEE Journal of Robotics and Automation, Vol.RA-2, No.3, pp. 135-145, Sept. 1986

5) Y.H.Liu, S. Kuroda, T. Naniwa, H. Noborio and S. Arimoto, "A Practical Algorithm for Planning Collision-Free Coordinated Motion of Multiple Mobile Robots", Proc. of the 1989 IEEE International Conference on Robotics and Automation, pp. $1427-1432,1989$

6) A. Klinger and C.R. Dyer, "Experiments on Picture Representation Using Regular Decomposition, "Computer Vision, Graphics, and Image Processing, Vol.5, pp. 68-105, 1976

7) S. Tanimoto and T.Pavlidis, "A Hierarchical Data Structure for Picture Processing, "Computer Vision, Graphics and Image Processing, Vol.4, pp: 104-119, 1975

8) D.H.Ballard and C.M.Brown, "Computer Vision," Prentice Hall 1982

9) H.Samet, "An Algorithm for Converting from Rasters to Quadtrees, "IEEE Trans. on Pattern Analysis and Machine Intelligence, Vol.PAMI-3, pp. 93-95, 1981

10) J.Pearl, "Heuristics-Intelligent Search Strategies for Computer Problem Solving," Addison-Wesley Publishing Company, 1984, Ch.1 pp. 14-15

11）市川，妹尾，宮田，“移動機械の自立制御，”計測自動制 御学会論文集, Vol..20，No.10，pp.87-91，1984

12) H.Samet, "Neighbor Finding Techniques for Image Represented by Quadtrees," Computer Vision, Graphics and Image Processing, Vol.18, pp.37-57, 1982

13) C.R.Dyer, A. Rosenfeld, and H. Samet, "Region Representation : Boundary Codes from Quadtrees," Commun. ACM, Vol.23, No.3, pp.171-179 March 1980

14) G. B. Dantzig, "Linear Programming and Extensions," The Rand Corporation Published Princeton Univ. Press 1963, Section 17-3 


\title{
A Fast Path-Planning Algorithm for a Mobile Robot Based on a Quadtree Representation*
}

\author{
Hiroshi NOBORIO** \\ Tomohide NANIWA*** Suguru ARIMOTO****
}

\begin{abstract}
Determination of a practical collision-free path for a mobile robot between start and goal positions in a workspace is central to design of an autonomous mobile robot. This paper presents a feasible path-planning algorithm which runs on the quadtree representation via a path graph. The quadtree representing the workspace is obtained from fats conversion of a real image taken through a camera on the ceiling. Thus, the algorithm can run even when obstacles in the workspace are shifted frequently. The quadtree also integrates obstacle regions and other regions in the workspace with a hierarchical structure in positioning. By using the hierarchical structure, the algorithm can select fast the practical collision-free path out of the quadtree without interference checking between the mobile robot and its obstacles. Moreover, the algorithm searches the path in the quadtree by way of the path graph. The path graph is initially defined by an arc with start and goal position's nodes, and the proposed algorithm gradually builds the path graph on the quadtree by the following processes synchronously : 1) Selection of the shortest path out of the path graph; and 2) Expansion of a part of the path graph along the shortest path so as to avoid the forbidden regions in the quadtree. By this synchronism, the algorithm can keep the size of the path graph as small as possible in connection with given two positions, and consequently it runs fast enough to be used practically even in any cluttered workspace. Finally, several experimental results show that the proposed algorithm is superior to some conventional algorithms in respect of the calculation time.
\end{abstract}

Key Words: Path-Planning, Quadtree Representation, Obstacle Avoidance, Intelligent Robot, Real Image

* Received August 24, 1988

** Department of Precision Engineering, Faculty of Engineering, Osaka Electro-Communication University

*** Department of Mechanical Engineering, Faculty of Engineering Science, Osaka University

**** Department of Mathematical Engineering and Information Physics, Faculty of Engineering, University of Tokyo 